\title{
Investasi Saham di Masa Pandemi COVID-19
}

\author{
Diana Tambunan \\ Universitas Bina Sarana Informatika \\ e-mail: diana.dtb@bsi.ac.id
}

\begin{abstract}
Abstrak - Pandemi COVID-19 telah memukul berbagai sektor, termasuk pasar saham dimana banyak orang ragu untuk berinvestasi saham. Banyak industri terkena dampak Covid-19 dimana sejak Maret 2020 Indeks Harga Saham Gabungan (IHSG) Bursa Efek Indonesia mengalami penurunan karena banyak investor menjual saham yang dimilikinya, tetapi sejak minggu ketiga Mei 2020 hingga awal Juni 2020 telah menunjukkan kenaikan yang mengindikasikan perdagangan saham mulai menunjukkan perbaikan. Penelitian ini bertujuan untuk menganalisis saham-saham sektor apa saja yang masih mampu bertahan di masa pandemi COVID-19, dengan menggunakan data volume perdagangan saham, Indeks Harga Saham Gabungan (IHSG), nilai kapitalisasi pasar mingguan dan bulanan dengan sampel 20 saham - saham tertinggi berdasarkan volume penjualan dan nilai transaksi di bursa saham Indonesia periode bulan Maret 2020 sampai dengan Juni 2020 yang diperoleh dari laporan mingguan Otoritas Jasa Keuangan (OJK) dan Laporan Bulanan Bursa Efek Indonesia (BEI). Hasil penelitian menunjukkan bahwa di masa pandemi COVID-19, para investor tetap dapat memperoleh keuntungan dalam berinvestasi saham apabila setiap keputusan yang dilakukan investor tersebut di dukung oleh perhitungan yang matang. Investor harus cermat dalam memilih sektor apa saja yang akan dituju. Investor perlu melakukan analisis fundamental agar tidak salah dalam menempatkan dana, dan melakukan diversifikasi saham untuk mengurangi risiko kerugian yang terlalu besar dalam berinvestasi. Jikas situasi kembali normal maka semua sektor akan bangkit kembali dengan penyesuaian - penyesuaian mengikuti protokol new normal. Saham-saham sektor industri konsumer, sektor telekomunikasi seperti data, tower dan sektor kesehatan seperti farmasi dan rumah sakit merupakan saham-saham yang dapat menjadi pilihan investor di masa pandemi COVID-19.
\end{abstract}

Kata Kunci: Investasi, portofolio saham, risiko dan return

\begin{abstract}
Abstrak - The COVID-19 pandemic has hit various sectors, including the stock market where many people hesitate to invest in stocks. Many industries were affected by Covid-19 where since March 2020 Jakarta Composite Index has decreased because many investors have sold their stocks, but since the third week of May 2020 until early June 2020 has shown an increase indicating stocks trading is starting to show improvement. This study aims to analyze which sector stocks are still able to survive in the COVID-19 pandemic, using Active Stocks by Total Trading Volume, Active Stocks by Total Trading Value on Indonesia Stock Exchange, weekly and monthly market capitalization values with a sample of Top twenty stocks based on Total Trading Volume and Total Trading Value, on the Indonesian Stock Exchange (IDX) from March 2020 to June 2020, The Financial Services Authority weekly Statistics and the Indonesia Stock Exchange Monthly Statistics. The results showed that during the COVID-19 pandemic, investors could still benefit from investing in stocks if every decision made by the investor was supported by careful calculations. Investors must be careful in choosing which sectors to go. Investors need to do a fundamental analysis so that they are not mistaken in placing funds, and diversification stocks to reduce the risk of loss which is too big to invest. If the situation returns to normal, all sectors will rise again with adjustments following the new normal protocol. Stocks of the consumer industry sector, the telecommunications sector such as data, towers and the health sector such as pharmaceuticals and hospitals are stocks that can be chosen by investors during the COVID-19 pandemic.
\end{abstract}

Keywords: investment, stock portfolio, risk and return

\section{PENDAHULUAN}

Pandemi virus corona (COVID-19) secara resmi ditetapkan sebagai pandemi oleh Organisasi Kesehatan Dunia (WHO) melanda lebih dari 150 negara di dunia. Jumlah orang di seluruh dunia yang terinfeksi masih terus meningkat secara agresif. COVID-19 telah mengubah dunia dalam banyak hal, seperti mengubah cara kita bekerja, belajar, beribadah, bersosialisasi, berolahraga, makan, tidur dan seterusnya. Untuk memperlambat penyebaran COVID-19, setiap orang sangat dianjurkan untuk menjaga jarak (physical distancing), menjaga kebersihan dan menggunakan masker. Berapa lama pandemi akan berlangsung dan dampak ekonominya sulit diprediksi. Pandemi COVID-19 memaksa kita untuk bertahan ditengah-tengah ketidakpastian (uncertainties). Namun belakangan pemerintah sudah 
mulai mencanangkan wacana transisi menuju new normal. Kondisi normal baru harus dihadapi dimana akan ada beberapa kebijakan yang diubah dan

dilonggarkan, termasuk soal berinvestasi, perlu dilakukan adaptasi dimana investor harus menyusun ulang portofolio yang dimiliki. Dalam lingkungan keuangan di tengah pandemi COVID-19, investor harus berhati-hati berportofolio investasi yang holistik dan beragam, sebab bursa saham di seluruh dunia rata-rata mengalami penurunan (Collins, 2020) begitu juga dengan Indeks Harga Saham Gabungan (IHSG) Bursa Efek Indonesia.

Investasi adalah suatu komitmen untuk menanamkan dana pada periode tertentu untuk mendapatkan pembayaran di masa depan sebagai kompensasi bagi investor untuk (1) Waktu selama dana diinvestasikan; (2) Tingkat inflasi yang diharapkan; dan (3) Ketidakpastian pembayaran di masa depan (Reilly \& Norton, 2007). Investasi terdiri dari investasi dalam bentuk aktiva riil (riil assets) seperti emas dan barang berharga lain, tanah, barangbarang seni atau real estate, dan investasi dalam bentuk surat-surat berharga atau sekuritas (marketable securities atau financial assets) yang mana tujuan berinvestasi untuk meningkatkan kekayaan, baik sekarang dan di masa depan. Keputusan investasi merupakan faktor penting dalam fungsi keuangan perusahaan. Fama (1974) menyatakan bahwa nilai perusahaan semata-mata ditentukan oleh keputusan investasi. Keputusan investasi sangat penting karena untuk mencapai tujuan perusahaan yaitu memaksimumkan kemakmuran.

Investor dalam menginvestasikan dananya berharap agar mendapatkan imbal hasil (return). Return adalah satu-satunya jalan yang paling masuk akal bagi investor untuk membandingkan berbagai alternatif investasi dengan berbagai macam hasil dari alternatif investasi tersebut (Jensen \& Jones, 2020). Jones (2006) mengatakan return merupakan rasio keuntungan atau kerugian dari sebuah investasi atau sejumlah uang yang diinvestasikan. Tujuan imbal hasil (return) untuk memenuhi kemakmuran investor. Return sebuah investasi diukur dari return yang diterima pada periode tertentu, biasanya satu tahun. Investor menginvestasikan sejumlah dananya untuk masa yang akan datang dan ketika masa itu tiba, investor dapat mendapatkan pengembalian sesuai strategi yang mereka lakukan agar hasilnya dapat sesuai dengan yang mereka harapkan, baik itu lebih rendah maupun lebih tinggi. Reilly and Norton (2007) mengatakan bahwa keuntungan yang didapat dari pasar modal berupa dividen dan capital gain yang merupakan hasil yang diperoleh dari selisih antara nilai jual dan nilai beli saham bila investor menjual saham tersebut.

Keberadaan pasar modal memiliki peran peningkatan aktivitas ekonomi nasional karena dengan adanya pasar modal, perusahaan akan lebih mudah memperoleh dana sehingga mendorong perekonomian nasional menjadi lebih maju. Pasar modal berfungsi sebagai wadah pengalokasian dana secara efisien antara investor dengan perusahaan dengan memperjualbelikan instrumen keuangan. Bagi investor sendiri, pasar modal berfungsi sebagai alternatif berinvestasi yaitu dengan memberikan keuntungan dengan sejumlah risiko tertentu. Reilly and Norton (2007) mendefinisikan risiko sebagai ketidakpastian dari hasil yang didapat di masa mendatang atau probabilitas dari kerugian atas pendapatan di masa mendatang. Terdapat dua jenis risiko dalam investasi yaitu: (1) Risiko non sistematis yaitu risiko yang dapat dieliminasi dengan cara diversifikasi atau berinvestasi dalam berbagai jenis saham dari berbagai sektor karena berasal dari kondisi internal perusahaan. Risiko ini hanya berdampak terhadap suatu saham atau sektor tertentu; (2) Risiko sistematis adalah risiko yang tidak dapat dieliminasi karena risiko ini berasal dari kondisi makro ekonomi atau pasar. Apabila risiko ini muncul dan terjadi maka semua jenis saham akan terkena dampaknya. Contoh risiko sistematis adalah risiko inflasi, risiko tingkat suku bunga, dan risiko pasar. Tandelilin (2010) mengatakan bahwa beberapa sumber risiko yang mempengaruhi besarnya risiko suatu investasi: (1). Risiko suku bunga. Perubahan suku bunga bisa mempengaruhi variabilitas return suatu investasi. Apabila suku bunga naik maka return investasi yang terkait dengan suku bunga (misal deposito) juga akan naik. Akibatnya minat investor akan berpindah dari saham ke deposito. Maka jika suku bunga meningkat, maka harga saham akan turun, dan sebaliknya; (2) Risiko pasar. Fluktuasi pasar secara keseluruhan dapat mempengaruhi variabilitas return suatu investasi. Fluktuasi pasar biasanya ditunjukkan oleh berubahnya indeks pasar saham secara keseluruhan. Perubahan pasar diperngaruhi oleh faktor seperti resesi ekonomi, kerusuhan, atau perubahan politik; (3) Risiko inflasi. Inflasi yang meningkat akan mengurangi daya beli rupiah yang diinvestasikan. Jika inflasi meningkat, investor biasanya menuntut tambahan premium inflasi untuk mengkompensasikan penurunan daya beli yang dialaminya; (4) Risiko bisnis adalah risiko dalam menjalankan bisnis suatu jenis industri.

Kondisi pasar sulit diperkirakan dan baru diketahui setelah peristiwa terjadi. Oleh karena itu, investor yang akan melakukan investasi di bursa efek harus senantiasa memonitor kondisi pasar efek. Ang (1997) mengatakan kondisi Bursa Efek pada dasarnya dapat dibedakan atas tingkat harga secara umum meningkat (bull market) dan tingkat harga secara umum menurun (bear market). Bull market adalah kondisi pasar yang menguntungkan. Perkembangan harga pada bursa efek, secara garis besar dapat dimonitor melalui kinerja rata-rata dan indeks pasar. Kinerja rata-rata mencerminkan perilaku harga dari sekelompok saham representatif pada waktu tertentu. Indeks pasar mengukur perilaku harga saat ini dari kelompok saham representatif 
relatif terhadap harga periode dasar. Investor membandingkan rata-rata harga dari berbagai waktu untuk menilai kekuatan dan kelemahan relatif pasar. Jika harga rata-rata atau indeks menunjukkan kecendrungan kenaikan harga-harga, bull market terjadi, bila sebaliknya maka bear market terjadi.

Investor perlu melakukan analisis fundamental untuk membuat keputusan dalam memilih saham mana yang akan dibeli untuk jangka panjang (Bodie, Kane, \& Marcus, 2009). Analisis fundamental adalah metode analisis yang didasarkan fundamental ekonomi suatu perusahaan yaitu menghitung nilai intrinsik dengan data keuangan perusahaan. Karena itulah teknik ini menitikberatkan pada rasio-rasio finansial perusahaan. Ross, Westerfield, and Jordan (2016) mengatakan bahwa analisis fundamental mempunyai konsep dasar bahwa nilai saham sebuah perusahaan tercermin dalam kinerja perusahaan tersebut.

\section{METODE PENELITIAN}

Studi literatur dilakukan dengan menganalisis jurnal-jurnal yang inline dan relevan dengan topik penelitian. Penelitian ini dibatasi hanya untuk mengetahui saham-saham apa saja yang bertahan selama pandemi COVID-19. Pengamatan dilakukan terhadap laporan transaksi saham-saham di Bursa Efek Indonesia dimulai sejak awal Maret 2020 hingga awal Juni 2020. Pemilihan periode tersebut berdasarkan pertimbangan bahwa pandemi COVID19 pertama kali ditemukan di Indonesia pada awal Maret 2020. Penelitian menggunakan data sekunder yang berasal dari Otoritas Jasa Keuangan (OJK), Bursa Efek Indonesia (BEI) dan Laporan Keuangan Emiten yang diperoleh dari masing-masing situs emiten.

\section{HASIL DAN PEMBAHASAN}

COVID-19 telah mendatangkan malapetaka didunia sejak ditemukan di Wuhan China pada akhir tahun 2019. Tidak hanya mempengaruhi kesehatan dan cara hidup manusia tetapi juga ekonomi dan pasar saham. Kehancuran pasar saham tidak dapat dihindari akibat COVID-19. Banyak bisnis-bisnis ditutup/bangkrut, pengangguran melonjak, kemiskinan meningkat, dan rasa ketakutan melanda banyak investor sehingga banyak investor menjual saham yang dimilikinya sehingga harga saham anjlok di seluruh bursa saham dunia.

Tabel 1. Perdagangan Saham di Bursa Efek Indonesia periode Maret - Mei 2020

\begin{tabular}{|l|l|l|l|}
\hline & IHSG & $\begin{array}{l}\text { Volume } \\
\text { Transaksi } \\
\text { (Millar } \\
\text { saham) }\end{array}$ & $\begin{array}{l}\text { Nilai } \\
\text { Perdagangan } \\
\text { (Rp.Triliun) }\end{array}$ \\
\hline $\begin{array}{l}\text { Maret } \\
\text { Minggu-1 }\end{array}$ & $5,498.54$ & 316.16 & 306.47 \\
\hline
\end{tabular}

\begin{tabular}{|l|l|l|l|}
\hline $\begin{array}{l}\text { Maret } \\
\text { Minggu-2 }\end{array}$ & $4,907.57$ & 347.81 & 345.58 \\
\hline $\begin{array}{l}\text { Maret } \\
\text { Minggu-3 }\end{array}$ & $4,194.94$ & 384.32 & 385.51 \\
\hline $\begin{array}{l}\text { Maret } \\
\text { Minggu-4 }\end{array}$ & $4,545.57$ & 418.38 & 423.99 \\
\hline $\begin{array}{l}\text { Maret } \\
\text { Minggu-5 }\end{array}$ & $4,623.43$ & 449.91 & 457.97 \\
\hline $\begin{array}{l}\text { April } \\
\text { Minggu-1 }\end{array}$ & $4,649.08$ & 482.30 & 487.93 \\
\hline $\begin{array}{l}\text { April } \\
\text { Minggu-2 }\end{array}$ & $4,634.82$ & 524.89 & 520.35 \\
\hline $\begin{array}{l}\text { April } \\
\text { Minggu-3 }\end{array}$ & $4,496.06$ & 561.99 & 553.00 \\
\hline $\begin{array}{l}\text { April } \\
\text { Minggu-4 }\end{array}$ & $4,716.40$ & 588.45 & 580.95 \\
\hline $\begin{array}{l}\text { Mei } \\
\text { Minggu-1 }\end{array}$ & $4,597.43$ & 614.17 & 604.15 \\
\hline $\begin{array}{l}\text { Mei } \\
\text { Minggu-2 }\end{array}$ & $4,507.61$ & 643.93 & 636.16 \\
\hline $\begin{array}{l}\text { Mei } \\
\text { Minggu-3 }\end{array}$ & $4,545.95$ & 688.67 & 691.70 \\
\hline $\begin{array}{l}\text { Mei } \\
\text { Minggu-4 }\end{array}$ & $4,753.61$ & 725.64 & 738.12 \\
\hline $\begin{array}{l}\text { Juni } \\
\text { Minggu-1 }\end{array}$ & $4,947.78$ & 770.08 & 785.04 \\
\hline
\end{tabular}

Sumber: OJK (Juni, 2020)

Tabel 1 menunjukkan bahwa Indeks Harga Saham Gabungan (IHSG) Bursa Efek Indonesia (BEI) pada minggu kedua Maret 2020 mengalami penurunan. IHSG berada dilevel 4,907.57 menurun dimana pada minggu pertama Maret 2020 pada posisi 5,498.54 sejak Presiden Republik Indonesia Jokowi Widodo pada tanggal 15 Maret 2020 konferensi pers di Istana Bogor menyerukan kepada seluruh rakyat Indonesia untuk bekerja, belajar, dan ibadah di rumah saja agar penyebaran Covid-19 bisa segera dihambat, indeks bergerak fluktuatif karena pandemi COVID19 melanda Indonesia. Pada minggu ketiga Mei 2020 hingga awal Juni 2020 menunjukkan tren kenaikan, IHSG berada di posisi 4,545.95 dan terus menanjak hingga ke posisi 4,947.78 pada minggu pertama Juni 2020 dikarenakan pelonggaran Pembatasan Sosial Berskala Besar (PSBB) dampak pandemi COVID-19 dengan dibukanya sejumlah kegiatan ekonomi dan bisnis seperti mal-mal dan pertokoan. Volume perdagangan saham perlahan terus meningkat. Pada minggu pertama Juni 2020, volume perdagangan tercatat sebanyak 770.08 milliar lembar saham, dengan nilai transaksi sebesar Rp 785.04 triliun.

Sejak pasien pertama Covid-19 di Indonesia dikonfirmasi awal Maret 2020, transaksi perdagangan di pasar saham mengalami fluktuatif. Indeks Harga Saham Gabungan (IHSG) terus terombang-ambing selama pandemi COVID-19. Naik turun pasar saham tersebut tidak hanya terjadi di Indonesia saja tetapi juga di belahan dunia manapun.

Ang (1997) mengatakan bahwa Nilai atau Harga Pasar (market price) adalah harga suatu saham pada pasar yang sedang berlangsung. Harga pasar inilah yang menyatakan naik turunnya suatu saham. Jika pasar bursa ditutup, maka harga pasar adalah 
harga penutupan (closing price). Jika harga pasar dikalikan dengan dengan jumlah saham yang diterbitkan (outstanding shares) maka didapatkan nilai pasar (market value). Nilai Pasar (Market Value) biasa disebut kapitalisasi pasar (market capitalization).

Tabel 2. Perkembangan Perdagangan Saham berdasarkan Sektoral Juni minggu ke 2-2020

\begin{tabular}{|l|l|c|}
\hline Sektoral & \multicolumn{1}{|c|}{ Kapitalisasi Pasar } & \\
\hline & \multicolumn{1}{|c|}{ Nilai (Rp) } & $(\%)$ \\
\hline Keuangan & $1,948,999,285,421,240$ & 34.54 \\
\hline $\begin{array}{l}\text { Industri } \\
\text { Konsumsi }\end{array}$ & $1,036,321,430,916,490$ & 18.36 \\
\hline Infrastruktur & $608,932,934,874,765$ & 10.79 \\
\hline Industri Dasar & $576,821,177,863,924$ & 10.22 \\
\hline Perdagangan & $543,364,568,407,854$ & 9.63 \\
\hline $\begin{array}{l}\text { Properti \& } \\
\text { Real Estate }\end{array}$ & $304,962,495,575,218$ & 5.40 \\
\hline Pertambangan & $296,056,138,934,952$ & 5.25 \\
\hline $\begin{array}{l}\text { Aneka } \\
\text { Industri }\end{array}$ & $263,673,423,140,037$ & 4.67 \\
\hline Pertanian & $64,222,211,053,508$ & 1.14 \\
\hline
\end{tabular}

Sumber: OJK, Juni 2020

Dari tabel 2 tampak bahwa saham yang memiliki nilai kapitalisasi pasar tertinggi adalah saham-saham yang berada pada sektor keuangan dengan kapitalisasi pasar sebesar Rp 34,54\%, kemudian diikuti dengan sektor industri konsumsi sebesar $18,36 \%$, sektor infrastruktur sebesar 10,79 $\%$, sektor Industri Dasar sebesar 10,22\%, Perdagangan sebesar 9,63\%, Properti \& Real Estate sebesar $5.40 \%$, Pertambangan sebesar $5.25 \%$, Aneka Industri sebesar $4.67 \%$, dan Pertanian sebesar $1.14 \%$.

Tabel 3. Data Perdagangan Top 20 Saham Bursa Efek Indonesia Bulan Maret-2020

\begin{tabular}{|c|l|l|}
\hline No. & \multicolumn{1}{|c|}{$\begin{array}{c}\text { Active Stocks by } \\
\text { Total Trading } \\
\text { Volume }\end{array}$} & \multicolumn{1}{|c|}{$\begin{array}{c}\text { Active Stocks } \\
\text { by Total } \\
\text { Trading } \\
\text { Value }\end{array}$} \\
\hline 1. & BBRI $(4,21 \%)$ & BBCA $(14,21 \%)$ \\
\hline 2. & TLKM $(2,58 \%)$ & BBRI $(12,00 \%)$ \\
\hline 3. & IPTV $(2,49 \%)$ & TLKM $(6,98 \%)$ \\
\hline 4. & CARE $(2,35 \%)$ & BMRI $(6,54 \%)$ \\
\hline 5. & MDKA $(2,33 \%)$ & ASII $(4,64 \%)$ \\
\hline 6. & LPKR $(1,77 \%)$ & BBNI $(4,54 \%)$ \\
\hline 7. & ANTM $(1,76 \%)$ & UNVR $(2,43 \%)$ \\
\hline 8. & TOWR $(1,71 \%)$ & MDKA $(2,18 \%)$ \\
\hline 9. & PGAS $(1,66 \%)$ & INTP $(1,58 \%)$ \\
\hline 10. & REAL $(1,66 \%)$ & NATO $(1,42 \%)$ \\
\hline 11. & ZINC $(1,54 \%)$ & PGAS $(1,31 \%)$ \\
\hline 12. & NATO $(1,52 \%)$ & UNTR $(1,15 \%)$ \\
\hline 13. & BMRI $(1,41 \%)$ & INDF $(1,13 \%)$ \\
\hline 14. & BRPT $(1,34 \%)$ & TOWR $(1,08 \%)$ \\
\hline 15. & TELE $(1,33 \%)$ & ICBP $(1,06 \%)$ \\
\hline 16. & ASII $(1,21 \%)$ & HMSP $(1,05 \%)$ \\
\hline 17. & VIVA $(1,20 \%)$ & TKIM $(0,98 \%)$ \\
\hline 18. & FREN $(1,18 \%)$ & PTBA $(0,97 \%)$ \\
\hline
\end{tabular}

\begin{tabular}{|l|l|l|}
\hline 19. & BBNI $(1,15 \%)$ & KLBF $(0,91 \%)$ \\
\hline 20. & CTRA $(1,15 \%)$ & SMGR $(0,91 \%)$ \\
\hline & $\%$ of Total Trading & $\%$ of Total Trading \\
& $35.5 \%$ & $67,1 \%$ \\
\hline
\end{tabular}

Sumber: BEI, Juni 2020

Tabel 3 menunjukkan pada bulan Maret 2020 saham-saham terbanyak diminati baik berdasarkan volume perdagangan maupun nilai perdagangan adalah saham-saham sektor keuangan seperti BBRI, BMRI, BBNI dan BBCA, Sektor telekomunikasi adalah saham-saham TLKM, , FREN, dan TOWR. Sektor media adalah saham-saham IPTV dan VIVA, Sektor kesehatan seperti saham-saham CARE dan KLBF. Sektor tambang adalah sahamsaham MDKA, ANTM, dan PTBA, Sektor konstruksi adalah LPKR, REAL, dan CTRA.

Tabel 4. Data Perdagangan Top 20 Saham

Bursa Efek Indonesia Bulan April-2020

\begin{tabular}{|c|l|l|}
\hline No. & \multicolumn{1}{|c|}{$\begin{array}{c}\text { Active Stocks by } \\
\text { Total Trading } \\
\text { Volume }\end{array}$} & \multicolumn{1}{|c|}{$\begin{array}{c}\text { Active Stocks } \\
\text { by Total } \\
\text { Trading } \\
\text { Value }\end{array}$} \\
\hline 1. & REAL $(5,34 \%)$ & BBRI $(13,47 \%)$ \\
\hline 2. & BBRI $(4,35 \%)$ & BBCA $(11,89 \%)$ \\
\hline 3. & INPP $(3,02 \%)$ & BMRI $(6,11 \%)$ \\
\hline 4. & TRIO $(2,97 \%)$ & TLKM $(5,50 \%)$ \\
\hline 5. & FREN $(2,70 \%)$ & ASII $(4,42 \%)$ \\
\hline 6. & PGAS $(2,06 \%)$ & BBNI $(3,06 \%)$ \\
\hline 7. & CARS $(1,94 \%)$ & INPP $(3,06 \%)$ \\
\hline 8. & ZINC $(1,78 \%)$ & BTPS $(2,33 \%)$ \\
\hline 9. & CARE $1,78 \%)$ & UNVR $(1,90 \%)$ \\
\hline 10. & TLKM $(1,56 \%)$ & PGAS $(1,90 \%)$ \\
\hline 11. & BRPT $(1,53 \%)$ & BRPT $(1,90 \%)$ \\
\hline 12. & ANTM $(1,46 \%)$ & MDKA $(1,78 \%)$ \\
\hline 13. & TOWR $(1,42 \%)$ & KLBF $(1,55 \%)$ \\
\hline 14. & PPRO $(1,41 \%)$ & TOWR $(1,25 \%)$ \\
\hline 15. & BRMS $(1,40 \%)$ & UNTR $(1,15 \%)$ \\
\hline 16. & DMAS $(1,28 \%)$ & SMGR $(1,09 \%)$ \\
\hline 17. & BULL $(1,25 \%)$ & TBIG $(1,07 \%)$ \\
\hline 18. & BMRI $(1,23 \%)$ & INDF $(1,06 \%)$ \\
\hline 19. & MDKA $(1,15 \%)$ & NATO $(1,04 \%)$ \\
\hline 20. & ELSA $(1,15 \%)$ & CPIN $(0,93 \%)$ \\
\hline & $\%$ of Total Trading & $\begin{array}{l}\% \text { of Total Trading } \\
64,7 \%\end{array}$ \\
\hline & $40.8 \%$ & \\
\hline
\end{tabular}

Sumber: BEI, Juni 2020

Tabel 4 menunjukkan pada bulan April 2020 saham-saham terbanyak diminati baik berdasarkan volume perdagangan maupun nilai perdagangan adalah saham-saham sektor konstruksi adalah REAL, PPRO dan DMAS. Sektor keuangan adalah BBRI, BMRI, BBCA, BBNI, dan BTPS. Sektor perdagangan adalah INPP, TRIO, CARS dan NATO. Sektor telekomunikasi adalah saham-saham FREN, TLKM, TOWR, dan TBIG. Sektor kesehatan seperti saham-saham CARE dan KLBF. Sektor tambang adalah saham-saham ZINC, ANTM, BRMS, MDKA dan ELSA. Sektor industri dasar adalah BRPT, SMGR dan CPIN. Sektor industri 
barang konsumsi adalah UNVR dan INDF.

Tabel 5. Data Perdagangan Top 20 Saham

Bursa Efek Indonesia Bulan Mei-2020

\begin{tabular}{|c|l|l|}
\hline No. & $\begin{array}{c}\text { Active Stocks by } \\
\text { Total Trading } \\
\text { Volume }\end{array}$ & \multicolumn{1}{|c|}{$\begin{array}{c}\text { Active Stocks } \\
\text { by Total } \\
\text { Trading } \\
\text { Value }\end{array}$} \\
\hline 1. & BNLI $(18,29 \%)$ & BNLI $(21,48 \%)$ \\
\hline 2. & BBRI $(4,91 \%)$ & BBRI $(10,43 \%)$ \\
\hline 3. & BHAT $(2,58 \%)$ & BBCA $(10,26 \%)$ \\
\hline 4. & CARE $(2,49 \%)$ & TLKM $(4,94 \%)$ \\
\hline 5. & PWON $(2,42 \%)$ & BMRI $(4,16 \%)$ \\
\hline 6. & PGAS $(2,09 \%)$ & ASII $(3,46 \%)$ \\
\hline 7. & ZINC $(2,01 \%)$ & BBNI $2,48 \%)$ \\
\hline 8. & TLKM $(1,78 \%)$ & ICBP $(2,06 \%)$ \\
\hline 9. & MDLN $(1,76 \%)$ & UNVR $(1,75 \%)$ \\
\hline 10. & BRIS $(1,46 \%)$ & PGAS $(1,56 \%)$ \\
\hline 11. & TBIG $(1,36 \%)$ & TBIG $(1,54 \%)$ \\
\hline 12. & REAL $(1,33 \%)$ & JSMR $(1,32 \%)$ \\
\hline 13. & MNCN $(1,29 \%)$ & PTBA $(1,27 \%)$ \\
\hline 14. & BULL $(1,21 \%)$ & BOGA $(1,24 \%)$ \\
\hline 15. & BMRI $(1,16 \%)$ & INDF $(1,06 \%)$ \\
\hline 16. & FILM $(1,15 \%)$ & HMSP $(1,01 \%)$ \\
\hline 17. & GIAA $(1,04 \%)$ & MNCN $(0,99 \%)$ \\
\hline 18. & TOWR $(1,03 \%)$ & INTP $(0,95 \%)$ \\
\hline 19. & PURA $(1,00 \%)$ & BTPS $(0,93 \%)$ \\
\hline 20. & BOGA $(0,99 \%)$ & BRPT $(0,92 \%)$ \\
\hline & $\%$ of Total Trading & $\%$ of Total Trading \\
\hline & $51,4 \%$ & $74,2 \%$ \\
\hline
\end{tabular}

Sumber: BEI, Juni 2020

Tabel 5 menunjukkan pada bulan Mei 2020 saham-saham terbanyak diminati baik berdasarkan volume perdagangan maupun nilai perdagangan adalah saham-saham sektor keuangan adalah BNLI, BBRI, BHAT, BBCA, BRIS, BMRI, BBNI dan BTPS. Saham sektor kesehatan adalah CARE. Sektor telekomunikasi adalah saham-saham TLKM, TOWR, dan TBIG. Sektor konstruksi adalah PWON dan MDLN. Sektor infrastruktur adalah PGAS, BULL, GIAA, PURA, dan JSMR. Sektor perdagangan adalah MNCN, FILM, dan BOGA. Sektor aneka industri adalah ASII. Sektor industri barang konsumsi adalah ICBP, UNVR, INDF, HMSP, dan INTP.

Rizvi, Mirza, Naqvi, and Rahat (2020) melakukan penelitian untuk menilai bagaimana keadaan COVID-19 yang berkembang apakah mempengaruhi kinerja dan gaya invetasi di seluruh Uni Eropah. Peneliti menilai kinerja masing-masing gaya investasi selama evolusi COVID-19. Hasil penelitian mereka menunjukkan bahwa penularan COVID-19 sangat dinamis di seluruh Uni Eropa sehingga COVID19 berdampak sangat buruk pada berbagai kategori reksadana di Uni Eropa, hanya dana kewirausahaan sosial yang menunjukkan pengembalian positif. Jerman dan Prancis adalah negara yang sebagian besar dipengaruhi oleh penyebaran virus corona yang berdampak sangat buruk. Sedangkan Swiss, Swedia, Irlandia, Austria dan Denmark tidak begitu buruk sehingga mengalami peningkatan investasi disebabkan para manajer dana memindahkan investasi dari lokasi yang terinfeksi secara signifikan seperti Jerman dan Prancis ke lokasi yang memiliki dampak COVID-19 yang lebih rendah seperti Swiss, Swedia, Irlandia, Austria dan Denmark. Investasi yang bertumbuh dengan baik di Uni Eropa selama pandemi COVID-19 adalah perusahaan-perusahaan yang bergerak dibidang utilitas, grosir dan ritel.

Phil (2020) seorang ahli pasar saham dunia melakukan penelitian mengenai bagaimana COVID-19 berdampak pada pasar saham. Hasil penelitiannya mengatakan bahwa saat pandemi COVID-19 adalah saat yang paling tepat untuk berinvestasi/membeli saham dimana banyak orang menjual saham sehingga harga saham sangat murah. Phil memberikan indikator yang dapat digunakan oleh investor agar tidak salah dalam memilih produk saham adalah dengan menjawab hal-hal berikut ini yaitu: (1) apakah permintaan produk saham tersebut tinggi; (2) apakah perusahaan penghasil produk tersebut sebagai pengontrol harga; (3) apakah produk yang dihasilkan perusahaan tersebut selalu dibutuhkan manusia dan tetap ada bila dibutuhkan; ataukah (4) produk yang dihasilkan merupakan produk berharga/memiliki nilai tinggi seperti energi, tenaga surya, makanan dan lain-lain, ataukah (5) produknya merupakan produk kemewahan yang diperlukan suatu kelompok tertentu. Selain itu, Phil berpendapat bahwa perusahaan yang sangat diuntungkan dengan adanya pandemi COVID-19 adalah industri makanan, alat kesehatan dan alatpembersih, sementara perusahaan lain mengalami kerugian yang amat parah.

Melihat perdagangan saham di Bursa Efek Indonesia sejak bulan Maret 2020 sampai dengan Mei 2020 dengan merujuk penelitian Rizvi et al. (2020) dan penelitian Phil (2020) maka saham-saham yang direkomendasikan untuk diinvestasikan selama masa pandemi COVID-19 di Bursa Saham Indonesia adalah sebagai berikut: (1) Investor sebaiknya membeli saham-saham sektor industri barang konsumer (consumer goods) karena sektor barang konsumer mampu mencatatkan kinerja positif sejak adanya pengumuman kasus COVID-19 pertama di Indonesia. Industri barang konsumer meningkat karena masyarakat pasti membutuhkan pasokan makanan dan minuman dalam kondisi apapun. Industri konsumer dipastikan akan selalu dicari konsumen karena erat dengan pemenuhan kebutuhan hidup karena meskipun aktivitas masyarakat dibatasi, tetapi konsumsi tentunya masih tetap berjalan; (2) Saham-saham sektor telekomunikasi juga bisa menjadi pilihan karena adanya semua kegiatan dirumah saja terkait adanya pandemi COVID-19 membuat fungsi telekomunikasi amat penting. Banyak perusahaan menerapkan kebijakan kerja dari rumah (work from home /WFH) dan pelajar/ 
mahasiswa menerapkan program belajar jarak jauh (elearning) mengakibatkan lonjakan (traffic) data internet untuk belajar online, penggunaan youtube, google, whatsApp meningkat sehingga penggunaan kuota data menjadi meningkat. Jaringan internet menjadi tumpuan untuk mendukung kelancaran bekerja dan belajar dari rumah. Begitu juga terjadi peningkatan permintaan pasang baru dibanding periode sebelum terjadi pandemi COVID-19.; (3) Saham-saham sektor kesehatan juga sangat menarik karena adanya peningkatan penjualan obat dan permintaan medical chek up, rapid test, swab test terjadi dalam masyarakat. Masyarakat harus mengeluarkan dana untuk membeli obat dan layanan kesehatan ditengah ancaman virus corona. Belum adanya vaksin dan ketidakpastian kapan pandemi berakhir membuat prioritas masyarakat saat pandemi adalah bagaimana menjaga kesehatan keluarga sehingga produk layanan kesehatan akan menjadi pilihan pertama dibanding konsumsi lainnya.

Bodie et al. (2009) mengatakan bahwa portofolio adalah kumpulan aset yang dimiliki investor. Investor perlu membangun portofolio beberapa aset yang akan memaksimalkan pengembalian untuk tingkat risiko tertentu. Demikian juga, dengan tingkat pengembalian yang diharapkan, seorang investor dapat membangun portofolio dengan risiko serendah mungkin. Markowitz (1952) pelopor teori portofolio modern membuat asumsi bahwa investor enggan mengambil risiko, artinya investor lebih suka portofolio yang kurang berisiko daripada yang berisiko untuk tingkat pengembalian tertentu. Ini menyiratkan bahwa seorang investor akan mengambil lebih banyak risiko hanya jika dia mengharapkan lebih banyak reward. Diversifikasi merupakan salah satu prinsip terpenting teori portofolio modern yang bermanfaat dalam mengurangi risiko atau ketidakpastian dengan cara meningkatkan jumlah saham dalam portofolio saham yang dapat menghasilkan return yang maksimal dengan risiko yang minimal. Diversifikasi adalah salah satu komponen utama pengambilan keputusan investasi di bawah risiko atau ketidakpastian (Koumou, 2020). Oyenubi (2019) mengatakan bahwa tidak ada angka unik dalam hal jumlah optimal stok yang diperlukan untuk mencapai diversifikasi penuh. Jumlah saham optimal yang dibutuhkan untuk mencapai diversifikasi penuh berbeda untuk pasar yang berbeda, dimana dalam mengukur diversifikasi saham, investor dapat menggunakan Portfolio Diversification Index (PDI).

\section{KESIMPULAN}

Saat ini kita hidup dimasa yang belum pernah terjadi sebelumnya dan tidak pasti, oleh karenanya jika investor tertarik dan berminat untuk berinvestasi saham di masa pandemi COVID-19 sebaiknya investor melakukan 2 hal yaitu: (1) analisis fundamental terhadap saham-saham yang akan dibeli dimana analisis fundamental membuat investor dapat mengetahui prospek perusahaan dan memprediksi return saham di masa mendatang; (2) diversifikasi saham dimana diversifikasi saham akan meminimalisir risiko yang akan terjadi pada investor karena Buffett and Cunningham (2019) mengatakan Don't put your eggs in one basket yaitu dalam berinvestasi perlu melakukan diversifikasi saham.

\section{REFERENSI}

Ang, R. (1997). Buku Pintar Pasar Modal Indonesia. Mediasoft Indonesia.

BEI. (2020). Laporan Keuangan dan Tahunan. Retrieved 30 Juni 2020, 2020, from https://www.idx.co.id/perusahaantercatat/laporan-keuangan-dan-tahunan/

Bodie, Z., Kane, A., \& Marcus, A. J. (2009). Investments. New York: Mc Graw Hill.

Buffett, W., \& Cunningham, L. A. (2019). The essays of Warren Buffett : lessons for corporate America.

Collins, C. N. (2020). Effect of COVID-19 Pandemic on Global Stock Market Values: A Differential Analysis. Acta Universitatis Danubius (Economica), 16(No.2).

Fama, E. (1974). The Empirical Relationships Between the Dividend and Investment Decisions of Firms. American Economic Review, 64(3), 304-318.

Jensen, G. R., \& Jones, C. P. (2020). Investments : analysis and management.

Jones, C. P. (2006). Investments: Analysis and Management; 10th edition. New York: John Wiley \& Sons.

Koumou, G. B. (2020). Diversification and portfolio theory: a review. Financial Markets and Portfolio Management. doi: 10.1007/s11408020-00352-6

Markowitz, H. (1952). Portfolio Selection. The Journal of Finance, 7(1), 77-91. doi: $10.2307 / 2975974$

OJK. (2020). Statistik Pasar Modal Indonesia. Retrieved 30 Juni 2020, 2020, from https://www.idx.co.id/perusahaantercatat/laporan-keuangan-dan-tahunan/

Oyenubi, A. (2019). Diversification Measures and the Optimal Number of Stocks in a Portfolio: An Information Theoretic Explanation. Computational Economics, 54(4), 1443-1471. doi: 10.1007/s10614-016-9600-5

Phil, T. (2020). How To Invest During A Pandemic : Covid-19 And The Stock Market. from Https://Www.Ruleoneinvesting.Com/Blog/Ho w-To-Invest/How-To-Invest-During-Pandemic/ 
Reilly, F. K., \& Norton, E. A. (2007). Investments. Mason, Ohio: Thomson/South-Western.

Rizvi, S. K. A., Mirza, N., Naqvi, B., \& Rahat, B. (2020). Covid-19 and asset management in EU: a preliminary assessment of performance and investment styles. Journal of Asset Management. doi: 10.1057/s41260-020-001723

Ross, S. A., Westerfield, R., \& Jordan, B. D. (2016). Fundamentals of corporate finance.

Tandelilin, E. (2010). Portofolio dan Investasi Teori dan Aplikasi. Yogyakarta: Kanisius. 